\title{
Cambrian Trilobites as Archives for Anthropocene Biomarkers and Other Chemical Compounds
}

\author{
Douglas L. John ${ }^{\mathrm{a}}$, Patricia M. Medeiros ${ }^{\mathrm{b}}$, Lydia Babcock-Adams ${ }^{\mathrm{b}}$, \\ and Sally E. Walker ${ }^{\mathrm{a}^{*}}$ \\ ${ }^{a}$ Department of Geology, University of Georgia, Athens GA 30602-2501, USA. \\ ${ }^{\mathrm{b}}$ Department of Marine Sciences, University of Georgia, Athens GA 30602-3636, USA. \\ *Corresponding author. \\ E-mail addresses: d.john@uga.edu (D.L. John), swalker@gly.uga.edu (S.E. Walker), \\ medeiros@uga.edu (P.M. Medeiros), 1cba92@uga.edu (L. Babcock-Adams).
}




\begin{abstract}
This study examined well-preserved trilobite fossils from the middle-Cambrian ( 507 million years ago) Wheeler Shale of Utah to determine the proportion of original marine biomarkers compared to later chemical overprints. Using a technique to characterize multiple biomarkers simultaneously, the fossils revealed more about modern terrestrial ecosystems and anthropogenic influence than they did about early Paleozoic oceans. Plasticizers, flame retardants, petroleum byproducts, and insect repellent comprised up to $96 \%$ of all compounds present in the trilobite exoskeletons, whereas the rest included biomarkers indicating algae, vascular plants (e.g., conifers), and biomass burning inputs. Importantly, contamination occurred despite measures taken to minimize it, highlighting the pervasiveness of anthropogenic contaminants in fossils. These compounds provide invaluable data concerning regional anthropogenic alteration, even though scientific papers usually do not report the types and diversity of contaminants. Scientists must therefore record the composition and amounts of these chemical contaminants because the potential for overprinting could also bias other geochemical measurements, such as stable carbon isotopes, highlighting the need to constrain the sources of contamination within samples. Although the middle Cambrian fossils appear to be excellently preserved, their chemical composition is mainly an Anthropocene overprint.
\end{abstract}

Keywords: Anthropocene; trilobite fossils; molecular biomarkers; contamination; middle Cambrian 


\section{Introduction}

The Anthropocene is mostly characterized by alteration to the Earth's surface, such as tropical deforestation (Malhi et al., 2014), urbanization (Steffen et al., 2007) and their resultant effects on biodiversity loss and climate change (Karl and Trenberth, 2003; Dirzo et al., 2014). However, the subsurface effects of physical anthropogenic influence, such as drilling and mining as forms of human bioturbation ('anthroturbation'), are just beginning to be explored (Zalasiewicz et al., 2014). In addition to subsurface physical alteration, we show that anthropogenic compounds can greatly affect the preservation of chemical biomarkers of ancient fossils that were buried in rock for $\sim 507$ million years.

Molecular biomarkers are a widely adopted biogeochemical tool to explore ancient communities in the fossil record (Brocks and Summons, 2005; Brocks et al., 2005; Grice et al., 2005; Olcott et al., 2005; Brocks and Schaeffer, 2008; Pawlowska et al., 2012; O’Malley et al., 2013). Even if well preserved for millions of years, rocks and fossils collected at or near the surface are exposed to modern compounds that can overprint the original chemical fossil record (Wischmann et al., 2002; Rasmussen et al., 2008; French et al., 2015). Those compounds are usually not reported in geological or anthropological analyses, but here we highlight the importance of these contaminants as markers for geographic anthropogenic change, both of the subsurface and through potential collection and handling bias.

A set of excellently-preserved middle Cambrian trilobites ( $507 \mathrm{Ma})$ from the Wheeler Shale, Utah, were examined using a multibiomarker approach which allowed for a comprehensive characterization of the biomarker record (Simoneit et al., 2014). This method reveals a number of chemical compounds indicative of ecosystems, unlike a priori targeting a specific biomarker chemical class (e.g., $n$-alkanes or fatty acids). While originally looking for 
Cambrian biomarkers, we found that the trilobites were extensively overprinted by mostly anthropogenic chemical compounds. Although the fossils were well preserved based on morphology, their chemical record was not. It is important that these chemical compounds are reported in Earth system analyses, as they provide a window into the subterranean effects of the Anthropocene that can be compared across geographic regions. In addition, contamination introduced during sample collection and handling could affect bulk carbon values, resulting in a biased interpretation of the record.

\section{Materials and Methods}

Trilobites were quarried commercially from shale beds that once represented a middle Cambrian ocean, now known as the Wheeler Shale of the Great Basin, Utah (USA). Fossils were from the Wheeler Formation, which was deposited within the House Range Embayment; the stratigraphic position represents the Bolaspidella polymerid trilobite zone of the mid-middle Cambrian (see Brett et al., 2009). Trilobites were collected by West Desert Collectors and Terra Trilobites, Delta, Utah, from rock depths up to five meters, using two methods: 1) typical geological collecting techniques (hereafter referred to as the "unprotected" set) and 2) protected from plastics during extraction, shipping and handling (the "protected" set). We kept each data set separate to compare the difference in the two collection techniques. The ptychopariid trilobite, Elrathia kingii, and the much smaller agnostid trilobite, Peronopsis interstricta, were used for analysis (Fig. 1). Petrographically, all had well preserved and complete calcite $\left(\mathrm{CaCO}_{3}\right)$ exoskeletons ( $\sim 10 \mu \mathrm{m}$ in thickness). Two each of protected and unprotected Elrathia were powdered, extracted using solvents and derivatized for molecular composition analysis (discussed below). Because Peronopsis is much smaller than Elrathia, two sets of eight 
specimens were powdered to yield two samples from the unprotected specimens; eight additional Peronopsis were powdered from the protected specimens, yielding one sample. Two sediment samples from the unprotected Wheeler Shale and sediment associated with each species from the protected set were also powdered for analysis. The trilobites and sediment were then prepared for biomarker analysis by gas chromatography-mass spectrometry (GC-MS; Supplementary Methods).

The GC-MS analysis yielded a profile of individual biomarkers present in each sample, following a multibiomarker method (Medeiros and Simoneit, 2007, 2008a, 2008b; Simoneit et al., 2014). This method allows for a simultaneous characterization of the different chemical classes spanning a wide range of polarities without a need to isolate certain chemical classes before analysis (Supplementary Table 1 shows recoveries for major individual compounds found in this study).

\section{Results and Discussion}

The ancient trilobites had extensive chemical overprints from non-Cambrian natural biomarkers and anthropogenic chemical compounds. Specimens contained a higher percentage of biogenic compounds among protected (59.2\%) than unprotected (23.6\%) exoskeletons and sediments, and anthropogenic concentrations were likewise lower among protected specimens (Table 1; Supplementary Table 2). Thus, despite deliberate efforts, protected specimens were not immune to contamination and could represent those introduced before and after collection. Chemical compounds found in trilobites indicated overprints by a terrestrial landscape and anthropogenic compounds, and revealed little if anything about the Cambrian seas in which these trilobites lived. 
Our exoskeletal and sediment samples contained more than 50 molecular biomarkers and anthropogenic organic compounds representing twelve chemical classes (Supplementary Table 2). Nine of the chemical classes indicate biogenic input from either microorganism biomass or terrestrial vegetation. Three classes were anthropogenic and in most samples constituted the preponderance of the biomarkers by concentration (Fig. 2; Table 1).

\section{Biogenic compounds}

Several natural biomarkers indicative of microbial and algal sources occurred in the samples. These biomarkers were present in both sediments and particularly in protected Elrathia exoskeletons (Table 1). Microbial and algal biomarkers comprised 5.1\% of total biomarkers in unprotected specimens, but $27.1 \%$ in protected specimens (Table 1). The low molecular-weight $\left(\leq \mathrm{C}_{20}\right)$ homologous series show a strong preference for even carbon numbers, especially $n$ alkanoic acids with a nearly total even-to-odd carbon preference $\left(\mathrm{C}_{14: 0}, \mathrm{C}_{16: 0}, \mathrm{C}_{18: 0}\right)$, and to a lesser degree $n$-alkanes, $n$-alkanols, and glyceride derivatives (Table 1 ), which is suggestive of microorganisms (Simoneit, 1977; Medeiros and Simoneit, 2008a). The phytosterols stigmasterol and sitosterol were minor in our samples, while cholesterol was found in slightly higher concentrations (Table 1). Stigmasterol and sitosterol are components of plant lipid membranes, but can also be detected in microalgae (Volkman et al., 1998). Cholesterol is considered a major animal sterol (Puglisi et al., 2003), but it is also a predominant compound in algal detritus (Goad, 1978; Medeiros and Simoneit, 2008a). The presence of all three sterols suggests algae as their most likely source.

Protected exoskeletons of Elrathia and their sediments contained saccharides (Table 1; Fig. 3). Saccharides comprised $28.0 \%$ of the plant-derived biomarkers among unprotected sediments 
and exoskeletons, but $64.6 \%$ among protected specimens. Levoglucosan, a product of burning cellulose from plant biomass during wildfires (Simoneit et al., 1999), was present in unprotected exoskeletons (Fig. 3A; Table 1). Glucose was the most common saccharide present in the sediment and was most abundant in protected Elrathia sediment (Fig. 3C; Table 1). However, glucose is ubiquitous to all life and not diagnostic of any specific source (Medeiros and Simoneit, 2007). Sucrose, indicative of general plant input, and mycose, indicative of fungal input, occurred primarily in unprotected sediments (Table 1).

Terrestrial plant biomarkers were also present in both trilobite species (Fig. 3A-B; Table 1) and in sediments (Fig. 3C-D). Plants comprised approximately $18.4 \%$ of biomarkers from unprotected specimens, and 32.1\% from protected (Table 1). The diterpenoid dehydroabietic acid, a conifer-specific biomarker (Otto and Wilde, 2001), occurred in sediment and some exoskeletons (Table 1). Lignin derivatives (vanillin and 3-methoxy-benzaldehyde, traditional vascular plant biomarkers, Opsahl and Benner, 1995) were also detected in the sediment (Table 1). Lignin phenols suggest a terrestrial flora, with diterpenoids indicating conifers.

Biomarkers for algae, ubiquitous throughout the Phanerozoic and in the modern biosphere, could represent modern or ancient algal sources, and their age cannot be readily discerned with biomarker context alone. However, terrestrial vegetation did not evolve until after the Cambrian, with the first land plants in the Ordovician (Wellman and Gray, 2000), the earliest known wildfires in the Silurian (Glasspool et al., 2004), and the earliest conifers in the Carboniferous (Henry, 2005). Biogenic compounds clearly younger than Cambrian in age indicate that biomarker overprinting from terrestrial sources has occurred during the history of these trilobites, most likely in recent times when they were exhumed near the surface. 


\section{Anthropogenic compounds}

Anthropogenic compounds represented the highest concentration of any compound class overall, and was the predominant group in all exoskeletons (Fig. 2; Table 1). Trilobite exoskeletons were generally enriched in anthropogenic organophosphines and plasticizers relative to their associated sediments (Table 1). Phthalates, which are plasticizers used in the plastic industry (Wittassek et al., 2011), and triphenylphosphine oxide (TPPO), a flame retardant additive in plastics (Weil and Levchik, 2009), were the most common anthropogenic markers among all samples. Peronopsis showed a particularly high concentration of phthalates relative to Elrathia (55638.2 $10^{-9} \mathrm{~g} \mathrm{~g}^{-1}$ to $2399.910^{-9} \mathrm{~g} \mathrm{~g}^{-1}$ average concentration, respectively; Table 1).

Anthropogenic compounds were also found in the sediments, ranging from $73.7 \%$ by weight in protected Peronopsis sediments to $3.8 \%$ by weight in protected Elrathia sediments (Fig. 2; Table 1). Anthropogenic compounds in sediments include $m$-toluamide and benzamide, which may be a degradation product of $N, N$-Diethyl-meta-toluamide (DEET), an insect repellent (Brown and Hebert, 1997; Pellegrino et al., 2011).

Phthalates adsorb more readily onto microcrystalline calcite and clay particles than on other siliciclastic sediments, mostly as a function of surface area (Sullivan et al., 1982). Sediment, composed of clays and micrometer-scale calcite particles, would be expected to have a much greater surface area, and therefore a higher concentration of plasticizers, than in exoskeletons; however, that is not what we found. Trilobites had more organophosphines and plasticizers in their skeletons than in the surrounding sediments, suggesting their calcareous exoskeletons are particularly effective adsorbents for organic compounds. In point of fact, calcium carbonate sorbents are used to clean up oil spills and scrub sulfur dioxide from coal-fired power plants (Patowary et al., 2015; Wei et al., 1997). 
An unresolved complex mixture (UCM) occurred in both unprotected and protected sediments. These mixtures can come from many natural (e.g., bitumens; Ventura et al., 2008) and anthropogenic sources, but are frequently associated with petroleum inputs (White et al., 2013; Fig. 3D, Supplementary Table 2). The presence of UCM in our samples could possibly represent contamination from airborne petroleum byproducts (such as automobile exhaust) that were deposited on the landscape, possibly reaching the samples similarly to biomass burning derived compounds.

\section{Contamination in fossils: composition, biases, and a way forward}

Clearly fossils archive much more than their ancient chemical record, with potentially multiple overprints resulting from in situ contamination to collection and handling. For example, the groundbreaking discovery of $2.7 \mathrm{Ga}$ biomarkers indicative of the rise of eukaryotes (Brocks et al., 1999), could not rule out contamination despite rigorous decontamination measures and cleaning (Rasmussen et al., 2008). Likewise, studies on Neanderthal genomic DNA are also not immune to contamination issues (Wall and Kim, 2007). While scientists abhor contamination and try to eliminate it, the types and amounts of overprinting chemicals should be reported, providing an important source of Anthropocene data. Depending on the type of contamination, other chemical signals may be compromised. For example, an investigation assessing past predominant source inputs (e.g., marine versus terrestrial organic matter) using bulk $\delta^{13} \mathrm{C}$ analysis can be biased by more recent contributions of organic compounds of terrigenous origin (similar to those observed in this study), resulting in more depleted bulk $\delta^{13} \mathrm{C}$ values, and consequently, in a misinterpretation of ancient organic processes. 
Anthropogenic compounds were pervasive in our samples. The clean signal in our laboratory blanks indicates that contamination did not occur during analysis (Supplementary Fig. 1), but were likely introduced by a combination of pre- and post-collection factors. While we cannot rule out that the microbial and algal biomarkers could be vestiges from a Cambrian marine ecosystem, we know that the terrestrial plant ecosystem was clearly not. Conifers and wildfires are dominant in the Wheeler Shale region today, and are likely modern in situ contamination. Organophospine, plasticizers and flame retardants could have entered the exoskeletons and sediments at any time. However, because the plastic contaminants were reduced in our protected samples, it is likely these chemicals were absorbed onto the trilobite exoskeletons during or after collection despite every effort to reduce their influence. This includes the byproducts of DEET, an insect repellent, which could have entered the trilobites during collection.

The high susceptibility of sediment and especially fossils to biogenic and anthropogenic contamination suggests that biogeochemical studies of fossil materials may need to better report their protective methodologies. Geological workers unfamiliar with trace organic analysis may not take sufficient steps to fully ensure their data do not represent any environmental or anthropogenic artifacts. The multibiomarker approach is particularly helpful in revealing the diversity of contaminants that could affect analyses.

Our multibiomarker analysis of Cambrian trilobites detected natural biomarkers and compounds indicative of the modern coniferous vegetation and of wildfires in the region, and pervasive anthropogenic compounds that could have entered the specimens at any time. Fossils collected with both traditional geologic field methods and with efforts to minimize contact with potential contaminants still contained many anthropogenic compounds. These compounds could potentially influence the broader geochemical record preserved in fossils, highlighting the utility 
of a multibiomarker approach to constrain the amount of potential contamination along with specific biomarkers of interest. In summary, these compounds provide invaluable data concerning regional anthropogenic alteration and their effects on the chemical preservational bias of fossils. While the middle Cambrian trilobites appeared to be excellently preserved, their chemical composition revealed a chiefly Anthropocene history.

\section{References}

Brett, C. E., Allison, P. A., DeSantis, M. K., Liddell, W. D., \& Kramer, A. Sequence stratigraphy, cyclic facies and lagerstätten in the Middle Cambrian Wheeler and Marjum Formations, Great Basin, Utah. Palaeogeogr. Palaeoclimatol. Palaeoecol. 277, 9-33 (2009).

Brocks, J. J., Logan, G. A., Buick, R., \& Summons, R. E. Archaean molecular fossils and the early rise of eukaryotes. Science 285, 1033-1036 (1999).

Brocks, J. J., Love, G. D., Summons, R. E., Knoll, A., Logan, G.A., \& Bowden, S. A. Biomarker evidence for green and purple sulphur bacteria in a stratified Palaeoproterozoic sea. Nature 437, 866-870 (2005).

Brocks, J. J. \& Schaeffer, P. Okenane, a biomarker for purple sulfur bacteria (Chromatiaceae), and other new carotenoid derivatives from the 1640 Ma Barney Creek Formation. Geochim. Cosmochim. Acta 72, 1396-1414 (2008).

Brocks, J. J. \& Summons, R. E. Biomarkers for early life. Biogeochemistry 8, 63-115 (2005).

Brown, M. \& Hebert, A. Insect repellents: An overview. JAAD 36, 243-249 (1997).

Dirzo, R., Young, H. S., Galetti, M., Ceballos, G., Isaac, N. J., \& Collen, B. Defaunation in the Anthropocene. Science, 345, 401-406 (2014). 
French, K. L., Hallmann, C., Hope, J. M., Schoon, P. L., Zumberge, J. A., Hoshino, Y., Peters, C. A., George, S. C., Love, G. D., Brocks, J. J. \& Buick, R. Reappraisal of hydrocarbon biomarkers in Archean rocks. Proc. Nat. Acad. Sci. 112, 5915-5920 (2015).

Glasspool, I. J., Edwards, D., \& Axe, L. Charcoal in the Silurian as evidence for the earliest wildfire. Geology 32, 381-383 (2004).

Goad, L. J. The sterols of marine invertebrates: composition, biosynthesis, and metabolites, in Marine Natural Products, P. J. Scheuer, Ed. (Academic Press, London, 1978), pp. 75172.

Grice, K., Twitchett, R. J., Alexander, R., Foster, C. B. \& Looy, C. A potential biomarker for the Permian-Triassic ecological crisis. Earth Planet. Sci. Lett. 36, 315-321 (2005).

Henry, R. J. Plant diversity and evolution: genotypic and phenotypic variation in higher plants. Cabi Publishing (2005), pp. 332.

Karl, T. R., \& Trenberth, K. E. Modern global climate change. Science, 302, 1719-1723 (2003).

Mahli, Y., Gardner, T. A., Goldsmith, G. R., Silman, M. R. \& Zelazowski, P. Tropical forests in the Anthropocene. Annu. Rev. Environ. Res. 9, 125-159 (2014).

Medeiros, P. M. \& Simoneit, B. R. T. Analysis of sugars in environmental samples by gas chromatography-mass spectrometry. J. Chromatogr. A 1141, 271-278 (2007).

Medeiros, P. M. \& Simoneit, B. R. T. Multi-biomarker characterization of sedimentary organic carbon in small rivers draining the northwestern United States. Org. Geochem. 39, 52-74 (2008a). 
Medeiros, P. M. \& Simoneit, B. R. T. Source profiles of organic compounds emitted upon combustion of green vegetation from temperate climate forests. Environ. Sci. Technol. 42, 8310-8316 (2008b).

Olcott, A. N., Sessions, A. L., Corsetti, F. A., Kaufman, A. J., \& de Olivera, T. F. Biomarker evidence for photosynthesis during Neoproterozoic glaciation. Science 310, 471-473 (2005).

O’Malley, C. E., Ausich, W. I. \& Chang, Y. Isolation and characterization of the earliest taxon-specific organic molecules (Mississippian, Crinoidea). Geology 41, 347-350 (2013).

Opsahl, S. \& Benner, R. Early diagenesis of vascular plant tissues: lignin and cutin decomposition and biogeochemical implications. Geochim. Cosmochim. Acta 59, 48894904 (1995).

Otto, A. \& Wilde, V. Sesqui-, di-, and triterpenoids as chemosystematic markers in extant conifers - a review. Bot. Rev. 67, 141-238 (2001).

Patowary, M., Pathak, K., \& Ananthakrishnan, R. A facile preparation of superhydrophobic and oleophilic precipitated calcium carbonate sorbent powder for oil spill clean-ups from water and land surfaces. RSC Adv. 5, 79852-79859 (2015).

Pawlowska, M. M., Butterfield, N. J. \& Brocks, J. J. Lipid taphonomy in the Proterozoic and the effect of microbial mats on biomarker preservation. Geology 41, 103-106 (2012).

Pellegrino, M., Steinbach, N., Stensmyr, M. C., Hansson, B. S. \& Vosshall, L. B. A natural polymorphism alters odour and DEET sensitivity in an insect odorant receptor. Nature 478, 511-514 (2011). 
Puglisi, E., Nicelli, M., Capri, E., Trevisan, M. \& Del Re, A. A. M. Cholesterol, $\beta$-sitosterol, ergosterol, and coprostanol in agricultural soils. J. Environ. Qual. 32, 466-471 (2003).

Rasmussen, B., Fletcher, I. R., Brocks, J. J. \& Kilburn, M. R. Reassessing the first appearance of eukaryotes and cyanobacteria. Nature 45, 1101-1104 (2008).

Simoneit, B. R. T. Diterpenoid compounds and other lipids in deep-sea sediments and their geochemical significance. Geochim. Cosmochim. Acta 41, 463-476 (1977).

Simoneit, B. R. T., Schauer, J. J., Nolte, C. G., Oros, D. R., Elias, V. O., Fraser, M. P.,

Rogge, W. F. \& Cass, G. R. Levoglucosan, a tracer for cellulose in biomass burning and atmospheric particles. Atmos. Environ. 33, 173-182 (1999).

Simoneit, B. R. T., Oros, D. R. \& Medeiros, P. M. Organic matter provenance and paleoenvironment in the Cretaceous on the Manihiki Plateau, South Pacific. Palaeogeogr. Palaeoclimatol. Palaeoecol. 409, 48-56 (2014).

Steffen, W., Crutzen, P. J., \& McNeill, J. R. The Anthropocene: are humans now overwhelming the great forces of nature? AMBIO 36, 614-621 (2007).

Sullivan, K. F., Atlas, E. L. \& Giam, C. S. Adsorption of phthalic acid esters from seawater. Environ. Sci. Technol. 16, 428-432 (1982).

Ventura, G. T., Kenig, F., Reddy, C. M., Frysinger, G. S., Nelson, R .K., Van Mooy, B., \& Gaines, R. B. Analysis of unresolved complex mixtures of hydrocarbons extracted from Late Archean sediments by comprehensive two-dimensional gas chromatography (GC $\times$ GC). Org. Geochem. 39, 846-867 (2008).

Volkman, J. K., Barrett, S. M., Blackburn, S. I., Mansour, M. P., Sikes, E. L., \& Gelin, F. Microalgal biomarkers: a review of recent research developments. Org. Geochem. 29, $1163-1179$ (1998). 
Wall, J. D. \& Kim, S. K. Inconsistencies in Neanderthal genomic DNA sequences. PLoS Genetics 3, e175, doi: 10.1371/journal.pgen.0030175, accessed 31 Jan 2017 (2007).

Wei, S. H., Mahuli, S. K., Agnihotri, R., \& Fan, L. S. High surface area calcium carbonate: Pore structural properties and sulfation characteristics. Ind. Eng. Chem. Res. 36, 21412148 (1997).

Weil, E. D. \& Levchik, S. V. Polystyrenes and Thermoplastic Styrene Copolymers. In Flame Retardants for Plastics and Textiles (Carl Hanser Verlag, 2009), pp. 35-57.

Wellman, C. H. \& Gray, J. The microfossil record of early land plants. Philos. Trans. R. Soc. London, Ser. B 355, 717-732 (2000).

White, H. K., Xu, L., Hartmann, P., Quinn, J. G. \& Reddy, C. M. Unresolved Complex Mixture (UCM) in coastal environments is derived from fossil sources. Environ. Sci. Technol. 47, 726-731 (2013).

Wischmann, H., Hummel, S., Rothschild, M. A. \& Herrmann, B. Analysis of nicotine in archeological skeletons from the Early Modern Age and from the Bronze Age. Anc. Biomol. 4, 47-52 (2002).

Wittassek, M., Koch, H. M., Angerer, J. \& Brüning, T. Assessing exposure to phthalates the human biomonitoring approach. Mol. Nutr. Food Res. 55, 7-31 (2011).

Zalasiewicz, J., Waters, C. N., \& Williams, M. Human bioturbation, and the subterranean landscape of the Anthropocene. Anthropocene 6, 3-9 (2014). 


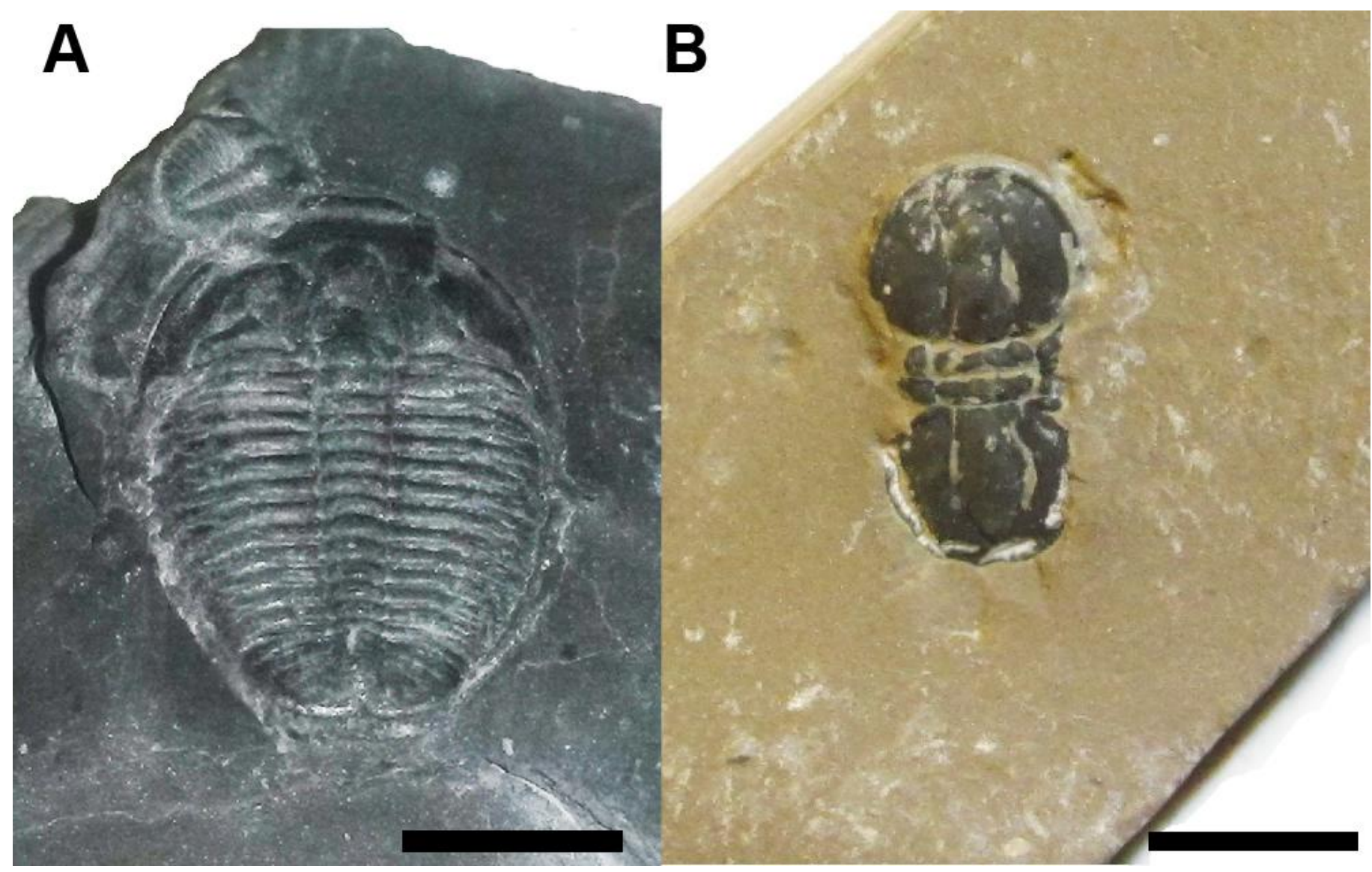

Fig. 1. Common Wheeler Shale trilobites used for multibiomarker analyses.

(A) The ptychoparid Elrathia kingii; (B) the agnostid Peronopsis. Scale bar $=0.5 \mathrm{~cm}$.

( 1 or 1.5 columns; image grayscale) 


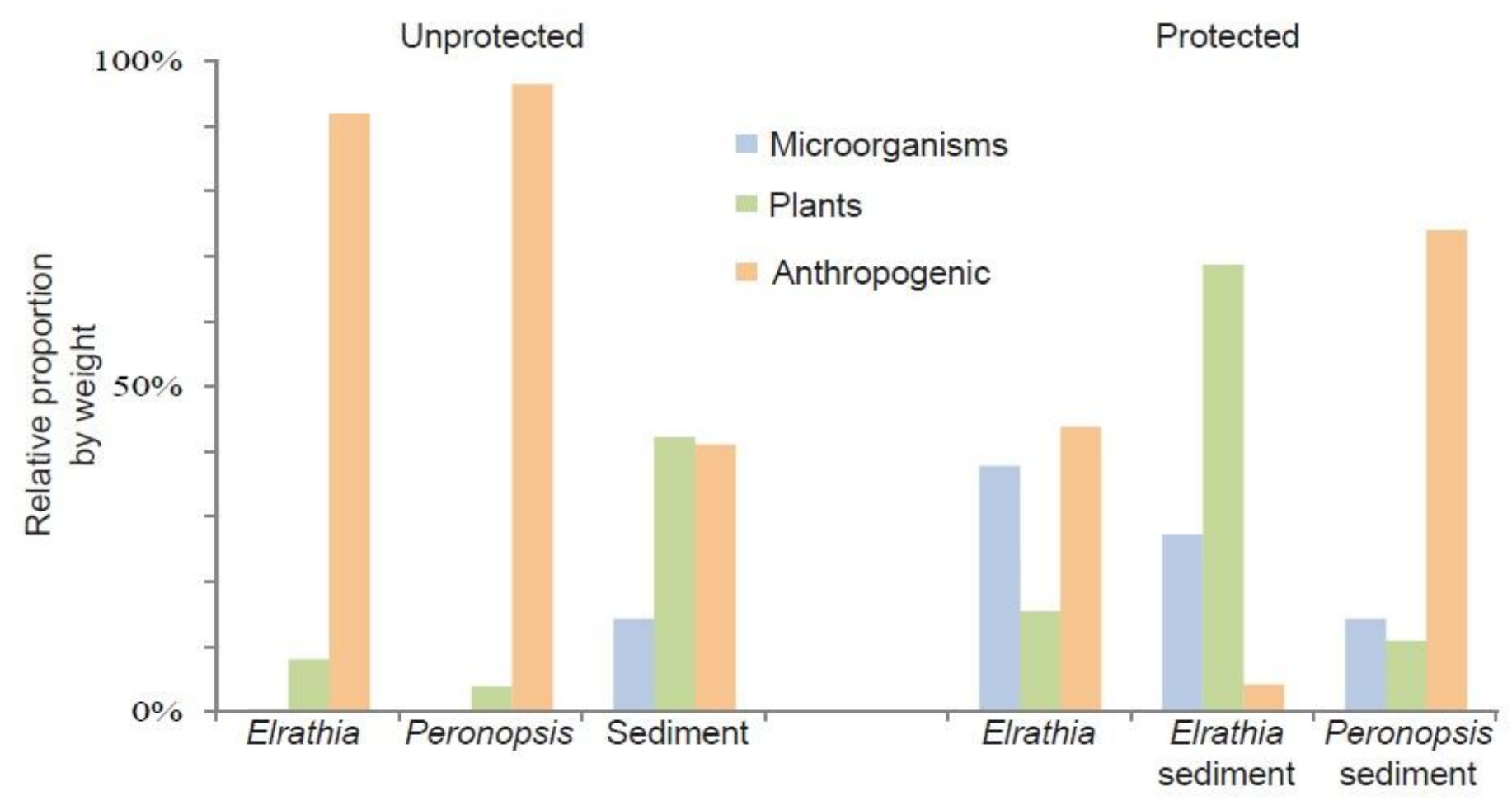

Fig. 2. Relative proportions of predominant biogenic and anthropogenic biomarkers and compounds. Relative proportions were calculated from mean concentrations by weight of compound classes for protected and unprotected trilobites and associated sediment, and color coded by biomarker/compound type.

(2 columns, color 

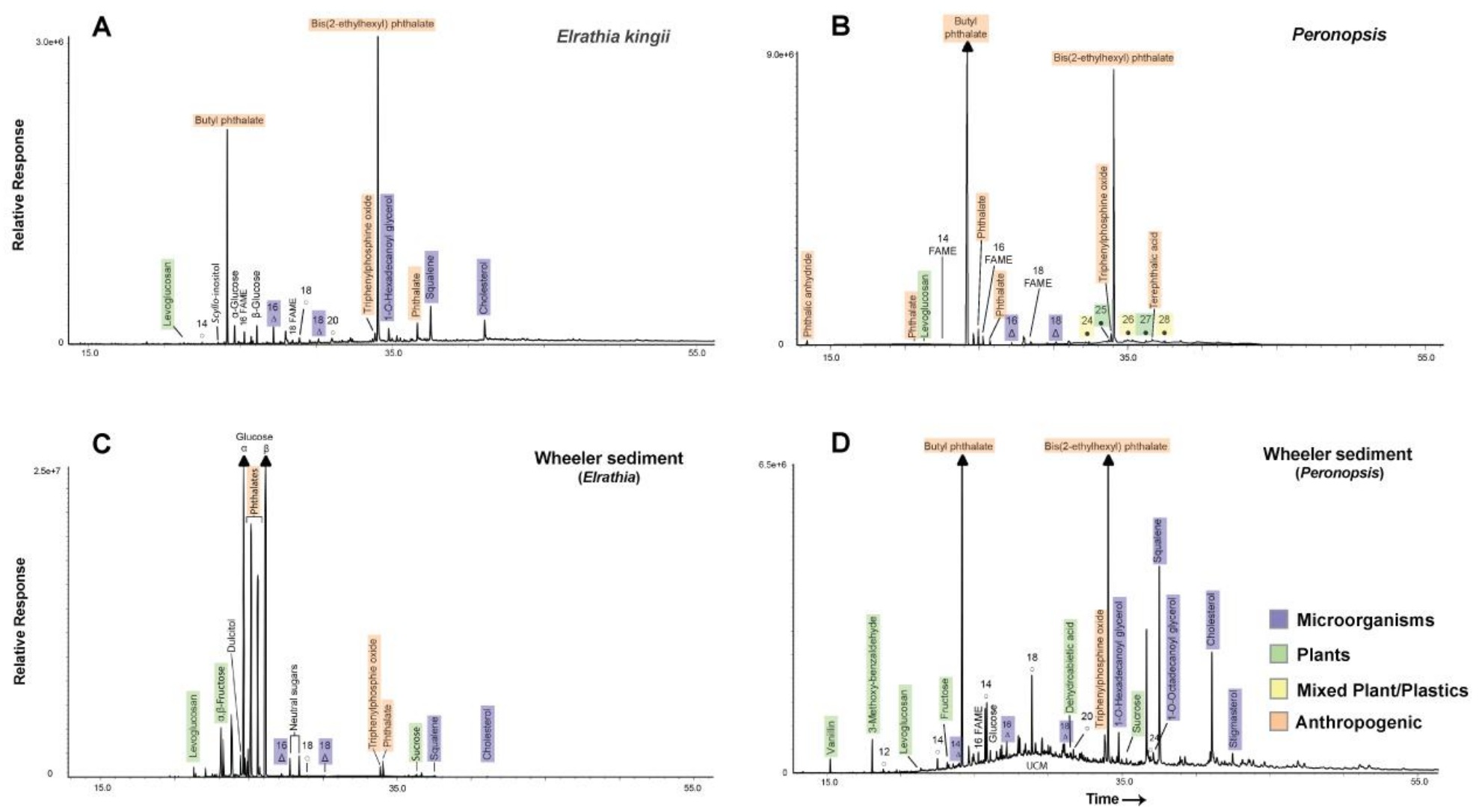

Fig. 3. GC-MS data for trilobites and sediments, Wheeler Shale, Utah.

Total ion current (TIC) traces of extract (trimethylsilyl derivatives) from (A) unprotected Elrathia; (B) unprotected Peronopsis; (C) sediment associated with Elrathia, and (D) sediment associated with Peronopsis. Numbers refer to the carbon chain length of homologous series $(\bullet=$ $n$-alkane, ${ }^{\circ}=n$-alkanol, $\Delta=n$-alkanoic acid, FAME $=$ fatty acid methyl ester, $\mathrm{UCM}=$ unresolved complex mixture).

( 2 columns, color) 
Table 1 - Average concentrations $\left(10^{-9} \mathrm{~g} \mathrm{~g}^{-1}\right)$ of chemical compounds in middle Cambrian trilobites, Elrathia and Peronopsis, and their associated sediments, from the Wheeler Shale, Utah. Compounds are organized by source interpretation, then by chemical class with sum of averages for each class. Blue color highlights indicate microorganism sources, yellow represents predominantly plastic sources, green represents terrestrial plant sources, and orange represents anthropogenic compounds. Unprotected samples were collected and stored using standard geological procedures, while protected samples were collected and handled without contacting plastics. Uncertainty in analyses of multiple replicates is on the order of $10 \%$.

Chemical compounds

Microorganism

LMW $(C \leq 20) n$-Alkanes

Heptadecane
Octadecane
Nonadecane
Eicosane

$$
\text { Total }
$$

LMW (C $\leq 20)$ n-Alkanols

Dodecanol
Tetradecanol
Eicosanol

$$
\text { Total }
$$

\section{LMW (C $\leq 20)$ n-Alkanoic acids}

Nonanoic acid

Tridecanoic acid

Tetradecanoic acid

Hexadecanoic acid

Octadecanoic acid

Total

\section{Sterols}

Cholesterol

Stigmasterol

Sitosterol

Microorganism
Microorganism
Microorganism
Microorganism

Microorganism

Microorganism

Microorganism

Microorganism

Microorganism

Microorganism

Microorganism

Microorganism

Fauna/Algae

Flora/Algae

Flora/Algae
Unprotected samples

Elrathia Peronopsis Sediment
Protected samples

Elrathia Peronopsis

Elrathia sediment sediment

\begin{tabular}{clc}
\multicolumn{3}{c}{ Protected samples } \\
\hline \multirow{2}{*}{ Elrathia } & $\begin{array}{l}\text { Elrathia } \\
\text { sediment }\end{array}$ & Peronopsis \\
& sediment
\end{tabular}

$\begin{array}{lccccc}0.0 & 0.0 & 6.5 & 0.0 & 0.0 & 0.0 \\ 0.0 & 0.0 & 24.2 & 7.0 & 0.0 & 1.7 \\ 0.0 & 0.0 & 24.6 & 0.0 & 0.0 & 0.0 \\ 0.0 & 0.0 & 5.7 & 0.0 & 0.0 & 4.3 \\ 0.0 & 0.0 & 61.0 & 7.0 & 0.0 & 6.0\end{array}$

$\begin{array}{lll}0.0 & 0.0 & 4.2\end{array}$

$\begin{array}{ll}0.0 & 0.0\end{array}$

0.8

$0.0 \quad 0.0$

22.2

1.5

0.0

4.0

0.0

0.0

0.0

0.0

0.0

2.5

0.0

26.4

1.5

0.0

7.3

\section{0}

0.0

2.2

0.0

0.0

0.0

1.3

0.0

0.0

0.0

0.0

0.0

0.0

26.4

1.5

5.9

13.1

1.0

\section{0}

0.0

0.0

0.0

2.2

430.4

1243.2

10.6

$1.3 \quad 28.6$

0.0

3.7

244.7

571.0

3.0

$681.0 \quad 1827.3$

14.6

$\begin{array}{lll}0.0 & 0.0 & 61.0\end{array}$

51.0

7.0

44.2

0.0

0.0

0.0

0.0

0.0

5.2

0.0

5.1

0.0

0.0

0.0 
Total

Glyceride derivatives

Glycerol

1-O-Hexadecanoyl glycerol

1-O-Octadecanoyl glycerol Total

Total Microorganism

Plant

\section{HMW (C > 20) n-Alkanes}

\begin{tabular}{l} 
Tetracosane \\
Pentacosane \\
\hline Hexacosane \\
\hline Heptacosane \\
\hline Octacosane \\
\hline Nonacosane \\
\hline Triacontane
\end{tabular}

Plastic mix

Plant

Plastic mix

Plant

Plastic mix

Plant

Plastic mix

Total

\section{HMW (C > 20) n-Alkanols}

Docosanol

Tetracosanol

Hexacosanol

Octacosanol

Total

\section{Saccharides}

Glucose

Fructose

Levoglucosan

Sucrose

Total

\section{Lignin derivatives}

3-Methoxy-benzaldehyde

Vanillin

Total

Plant
Plant
Plant
Plant

Plant
Plant
Plant
Plant

C.

General biomass

Plant

Plant burning

Plant

Conifer

Dehydroabietic acid

Total Plant

\section{Anthropogenic}

Amides

Benzamide

Insect repellent

$m$-Toluamide

Insect repellent

Total

Organophosphines
0.0

$\begin{array}{lll}48.0 & 215.1 & 0.0 \\ 43.4 & 342.8 & 6.0 \\ 63.6 & 482.4 & 0.0 \\ 45.8 & 410.4 & 0.0 \\ 30.6 & 335.5 & 0.0 \\ 25.1 & 226.6 & 0.0 \\ 15.1 & 162.2 & 0.0 \\ 71.6 & 2175.0 & 6.0\end{array}$

0.0

0.0

2.9

7.1

10.0

0.0

0.0

0.0

0.0

0.0

0.0

0.0

0.0

0.0

0.0

0.0

48.6

0.0

48.6

0.0

0.0

0.0

0.0

0.0

0.0

$\begin{array}{llll}66.1 & 51.0 & 7.0 & 49.4\end{array}$

4.3

17.7

0.0

0.0

0.0

2.5

15.9

0.0

6.5

0.0

0.0

1.1

15.9

0.0

7.6

181.7

756.

1834.3

84.9

0.0

0.0

0.0

0.0

0.0

0.0

0.0

0.0

0.0

0.0

0.0

0.0

0.0

0.0

0.0

0.0

0.0

0.0

0.0

0.0

0.0

0.0

0.0

0.0

0.0

$\begin{array}{lll}0.0 & 0.0 & 2.8\end{array}$

$0.0 \quad 0.0$

2.8

0.0

57.1

9.6

0.0

18.4

26.7

9.9

0.9

23.0

19.5

0.9

49.6

$\begin{array}{ccc}274.2 & 3914.1 & 2.7 \\ 0.0 & 560.3 & 0.0 \\ 1.8 & 15.7 & 1.2 \\ 14.0 & 22.5 & 2.1 \\ 290.0 & 4512.6 & 6.0\end{array}$

$\begin{array}{lll}0.0 & 0.0 & 3.0\end{array}$

519.4

0.0

0.0

8.2

0.0

0.0

3.9

0.0

0.0

12.1

281.6

2223.6

2.8

1.0

2.5

$\mathbf{3 1 2 . 3} \quad \mathbf{4 5 1 4 . 5}$

70.2

$\begin{array}{lll}0.0 & 0.0 & 5.2 \\ 0.0 & 0.0 & 4.2 \\ 0.0 & 0.0 & 9.4\end{array}$

0.0

0.0

0.0

0.0

0.0

0.0

0.0

0.0 


\begin{tabular}{|c|c|c|c|c|c|c|c|}
\hline Tributylphosphine & Anthropogenic & 9.2 & 23.8 & 0.0 & 0.0 & 0.0 & 0.0 \\
\hline Triphenylphosphine oxide & Flame retardant & 722.3 & 710.9 & 10.1 & 35.0 & 14.1 & 15.4 \\
\hline Total & & 731.5 & 734.7 & 10.1 & 35.0 & 14.1 & 15.4 \\
\hline \multicolumn{8}{|l|}{ Plasticizers } \\
\hline Terephthalic Acid & Plastics & 0.0 & 58.7 & 23.1 & 0.0 & 0.0 & 0.0 \\
\hline Butyl phthalate & Plastics & 1649.1 & 41349.9 & 185.7 & 197.1 & 45.1 & 204.7 \\
\hline Butyl hexyl phthalate & Plastics & 36.4 & 934.3 & 138.8 & 48.6 & 36.1 & 52.6 \\
\hline Bis(2-ethylhexyl) phthalate & Plastics & 714.4 & 13137.8 & 127.9 & 583.8 & 156.0 & 162.6 \\
\hline Phthalic Anhydride & Plastics & 0.0 & 157.5 & 0.0 & 0.0 & 0.0 & 0.0 \\
\hline Total & & 2399.9 & 55638.2 & 475.5 & 829.5 & 237.2 & 419.9 \\
\hline Total Anthropogenic & & 3131.4 & 56372.9 & 495.0 & 864.5 & 251.3 & 435.3 \\
\hline \multirow[t]{2}{*}{$\%$ Biogenic } & & 8.3 & 3.8 & 58.6 & 55.3 & 96.2 & 26.3 \\
\hline & & \multicolumn{3}{|c|}{ Average, all unprotected: 23.6} & \multicolumn{3}{|c|}{ Average, all protected: $\mathbf{5 9 . 2}$} \\
\hline$\%$ microorganism & & \multicolumn{3}{|c|}{ Average, all unprotected: 5.1} & \multicolumn{3}{|c|}{ Average, all protected: 27.1} \\
\hline$\%$ plant & & \multicolumn{3}{|c|}{ Average, all unprotected: 18.4} & \multicolumn{3}{|c|}{ Average, all unprotected:32.1 } \\
\hline \multirow[t]{2}{*}{ \% Anthropogenic } & & 91.7 & 96.2 & 41.4 & 44.7 & 3.8 & 73.7 \\
\hline & & \multicolumn{3}{|c|}{ Average, all unprotected: 71.4} & \multicolumn{3}{|c|}{ Average, all protected: 40.8} \\
\hline
\end{tabular}

\section{(Table printed in color)}

